DOI: 10.17516/1997-1370-0553

УДК 378.064.3:316.48

\title{
The Possibilities of Empathy in Preventing Interpersonal Conflicts in the Educational Environment of a Higher Education Institution
}

\author{
Olga G. Smolyaninova*a, Svetlana T. Posokhova ${ }^{b}$ \\ and Margarita Kh. Izotovab \\ ${ }^{a}$ Siberian Federal University \\ Krasnoyarsk, Russian Federation \\ ${ }^{b}$ Saint Petersburg State University \\ St. Petersburg, Russian Federation
}

Received 19.01.2020, received in revised form 23.01.2020, accepted 10.02.2020

\begin{abstract}
The present article studies the possibilities of empathy in preventing interpersonal conflicts in the sphere of higher education. Interpersonal conflicts are regarded from the sociopedagogical perspective as a complex phenomenon, the emergence and development of which is predetermined by the personal features of the participants of the education process. The success of mediation in a conflict between learners is determined by the knowledge of factors that decrease the probability of a conflict situation. Empathy is one of the personal features that may be employed to prevent conflict situations and to expand the range of applicable mediation technologies. The empirical study was carried out with students majoring in psychology, medicine and technical science aged from 18 to 24 . The empathy level diagnostic questionnaires by V.V. Boyko and A. Megrabian were used. It was found that the psychology students feature the best developed empathy. Empathy brings the learners together, cuts down aggressive tendencies, blocks competitive attitude towards students with special needs. Empathy develops the fundamental neutral relations between conflicting parties, which is essential to prevent interpersonal conflicts. A conclusion on the importance of developing empathic capacity of the students majoring in mediation is made.
\end{abstract}

Keywords: interpersonal conflict, mediation, psychology of conflict, empathy, neutrality, adolescence.

The material was prepared within the framework and sponsorship of the project powered by the Russian Foundation for Basic Research (RFFR). No. 18-013-00528 "The study of mediation practices in the field of education for harmonization of interethnic relations in a multicultural environment".

\footnotetext{
(C) Siberian Federal University. All rights reserved

* Corresponding author E-mail address: smololga@mail.ru ORCID: 0000-0002-5597-6348 (Smolyaninova)
} 
Research area: social sciences.

Citation: Smolyaninova, O.G., Posokhova, S.T., Izotova, M.Kh. (2020). The possibilities of empathy in preventing interpersonal conflicts in the educational environment of a higher education institution. J. Sib. Fed. Univ. Humanit. Soc. Sci., 13(2), 219-233. DOI: 10.17516/1997-1370-0553.

\section{Introduction}

Modern reality makes every person face the interests and convictions of the surrounding people. The clashes may occur due to different reasons and various objective and subjective factors, such as the developed sociocultural situation and the personal features of the individuals. These clashes often result in a conflict. Today, the problem of conflicts occupies a strong position among the most urgent problems of psychology. There are both theoretical and practical studies dedicated to the comprehensive conceptual insight of the conflict problem (Panferov, 2015). There is a wide range of different ideas of the essence and reasons of conflicts in the social environment. Thus, N.V. Grishina studies conflict as a bipolar phenomenon, a confrontation of two parties that manifests itself in their activities intended to overcome the misunderstanding; at that, any of the conflict parties is represented by an active subject (subjects) (Grishina, 2005). B.I. Khasan and P.A. Sergomanov suppose that every concept presents an actualized confrontation, i.e. clash of mutually opposing values, mindsets, and motives (Khasan, Sergomanov, 2003).

In the context of modern education, interpersonal conflicts in a higher educational institution appear to be an especially vibrant topic. An interpersonal conflict is understood as an open collision of interacting subjects caused by a contradiction of their opposite targets, incompatible in a certain situation (Khasan, Sergomanov, 2003). In an interpersonal conflict it is not the contradiction itself that is of major importance; it is the deepness of the personal stress and the vector of its influence on the behaviour of the conflicting parties.

According to L.S. Vygotsky, the contradictions perceived by a person in various social standards, types of behaviour and reaction are interiorized. However, it does not mean that once interiorized, these contradictions are adequately resolved (Kholina, Petrova, 2017).

\section{Methodological provisions \\ of the problem}

Conflicts occur in every domain of human activity: in everyday and professional life, in the social, political, or cultural spheres (Panferov, 2015). At the present moment, special attention is paid to the development of conflict resolution culture at higher educational institutions. The changing socioeconomic relations, the growing need for highly qualified people in industry and society, the modernizing Russian education and active implementation of new information technologies into the college curricula make a direct impact on the education system and its subjects (Posokhova, Shemeteva, 2017). The transformation of status and roles of both professors and learners, the changes of the social and personal significance of higher education, as well as the changes in the hierarchy of values etc. are clear tendencies in education. These are the factors that underlie the conflicts that may occur in the college environment.

A distinctive feature of the conflicts at a higher educational institution is the development against the background of interference of the transformations that take place in the society and the changes caused by the personal and lifespan development of students as the main object of education. On one hand, the education environment reflects all the contradictions of social development like a hologram. Naturally, it complicates the processes and mechanisms of development and learning. Despite all social difficulties, the pedagogical process is aimed at preparing the young generation for living in the continuously changing society, at creating new opportunities for the learners to develop their own models of behaviour, to find their personal and moral ideals. Moreover, today higher education is forced to concentrate on more than 
just knowledge, skills and abilities to be transferred to the students together with the efficient professional competences. Today, the educational process has to focus on shaping and developing the personalities able to successfully communicate with their future colleagues.

On the other hand, the conflicts occur against the background of complex and diverse processes of personal becoming and age-specific development. Student age is the period of intensive psychological, personal, and intellectual changes. The main achievements of this age include getting accepted and recognized in various social communities, adoption of new roles, development of socially responsible behaviour. Ability to adapt to the new life conditions to a great extend depends on the personal qualities of the students. Even though young people continue applying the life skills they have acquired at the previous development stages, they get to realize that they need some new strategies of interaction with the world around them and, first of all, with different communities of people.

The problem of conflicts is aggravated by the significant changes that happen to the communication sphere in adolescence, as young people develop their individual style of communication, the need for belonging to a certain group and relationships etc. This is the period when a young person is striving to understand himself, to assess his abilities, to establish positive relations with the environment, which is not always welcoming, causing the growth of neurotic disorders. Social factors, lifestyle, psychological and emotional conditions may create the psychological factors that make a strong impact on the academic success of the student. At the same time, all these processes occur against the background of the transforming modern society, i.e. the change of the economic, political, and cultural values. The social problems are aggravated by psychophysiological and personal factors, bringing the young person into a complicated life situation (Titkova, 2004).

The increasing conflict situation within the higher education community is described in multiple psychological and pedagogical studies (Gomyranova, 2006; Krasnoperova,
2016; Chiker, 2019). The psychological and pedagogical concepts of conflict resolution are developing respectively (Gurieva, 2015; Gurieva, Udavikhina, 2019). At the present moment, there is a number of experimental researches of conflicts that occur between students. They are dedicated to the pedagogical basics of conflict resolution studies in the education process of the college, the behaviour strategies of students of different majors in interpersonal conflicts, the intra-group conflicts of students, and students' conflict resolving capacity (Mikhaylova, 2004; Titkova, 2004).

However, such mechanism of regulating interpersonal conflicts between students as empathy still remains understudied. The differences in the moral mindsets, standards, values, and behaviour always bring students to conflict situations, which may yield either an interpersonal conflict or a conflict with the entire group (Utlik, 2010; Savva, Soldatchenko, 2015). The most common reasons of conflicts that occur at higher educational institutions are: inadequate assessment and self-assessment of both students and professors; differences in the systems of values; interpersonal conflicts of students; insufficient culture of communication; lack of knowledge of the efficient social and pedagogical technologies of group organization; misunderstanding between the subjects of the educational and nurturing process; personal peculiarities, such as characters, temperaments, manners etc. (Smolentseva, 1998).

The evolution of the scientific idea of conflict psychology inevitably calls for new ways of conflict regulation, for the search of new efficient technologies and express methods. There is no wonder that mediation as an alternative conflict resolution technology involving a third party is getting more and more popular. The key feature of mediation is the provision of a neutral, unbiased, impartial assessment of all components of the conflict situation. The need for mediation technologies and their efficiency in resolving conflicts between students is doubtless; it has been proven with theory and practice (Smolyaninova, Korshunova, 2019; Smolyaninova, Popova, 2019). To prevent a conflict, it is important to understand the behaviour of the counterpart deeply and 
objectively, to comprehend his or her current emotional condition, intentions and attitude towards others. The psychological mechanisms of perception and understanding in interpersonal communication include identification, social perception, and empathy. It is important to highlight the organic connection of empathy and mediation. As the President of the National Organization of Certified Mediators, Ts.A. Shamlikashvili emphasizes the importance of empathy in the mediation processes. From her point of view, the ability to get along, to maintain proper communication and steering it in the right direction, approaching to resolution of any conflicts with tact and prudence is determined by empathy. Empathy is nothing but the underlying competence of a mediator (Shamlikashvili, 2014). Works by foreign authors have pointed out that empathy is one of the key competences of practicing mediators, which requires continuous training to facilitate both professional and personal growth of mediators (Lieberman, Foux-Levy, Segala, 2005).

Building a strategy of communication between two people in the situation of getting to know each other, both partners have to take more than their own needs, motives, and mindsets into account, but also those of their counterpart. As experience, empathy arises in a certain situation of communication between people; this is the situation which manifests, first of all, the system of values of the individual (Eleferenko, 2010).

Empathy is what helps a person find the way around different circumstances and communicate with different people, as well as settle the arising conflicts (Kariagina, Ivanova, 2013). Psychology interprets ability to empathize as emotional responsiveness and affection to other people, recognition of their joys and sorrows. Empathy manifests itself in one's wish to help and support other people.

The researchers distinguish two components of empathy: 1) emotional (affective) component as a reaction to another person, automatic sharing the emotion condition of another; 2) cognitive ability to accept the perspective of another, at the same time recognizing oneself as a separate personality (Jackson et al., 2005, Christian, 2008). C. Gonzalez-Liencres defines empathy as an ability of a person to form a representation of the emotional state of another person through objectivizing it in him or herself, at the same time realizing the reason which caused that emotional state in their counterpart.

Such attitude implies development of the humanistic values the complete self-actualization of a person would be impossible without. As the person is getting to know himself and his uniqueness deeper, he is getting more sensitive and able to recognize the individuality and uniqueness of others. This is why the development of empathy follows the personal growth and is known to be one of its basic features.

In communication, empathy facilitates the balance in interpersonal relations; it makes human behaviour socially induced. Settling into a social role, getting used to all of its attributes, status, position, improving the professional qualities in many spheres is impossible without empathy. Thus, empathy is one of the important personal and professional qualities of any specialist working in the "person-person" system. Empathy is essential for the assisting specialists, e.g. psychologists, doctors, teachers, social workers, mediators.

Among competences of a mediator, a great role is played by the active (empathic) listening technique. During the mediation procedure, the intermediary uses his posture, face expression, eye contact and words to demonstrate that he is actively listening to his clients. It is extremely important for a mediator to keep the behaviour well-balanced and natural, not to interfere in the personal space of the other, but at the same time not to appear indifferent and distant. The mediator should demonstrate attention to each of the partners, so that none of them feel abandoned or neglected. Placing a high priority on active listening technique in mediation, Ts.A. Shamlikashvili remarks that empathy is impossible without combining the cognitive perception with the perception through the heart; without acceptance, respect, desire and readiness to understand; without the ability to hear both the message ("what") and the feelings and emotions behind it ("how"); without a non-judgemental approach (Shamlikashvili, 2010). 
Just like many others, these specialists find themselves in a continuous emotional contact with a big number of people, in charge of their health, mental well-being, and the assistance they will get. For this reason, at the earliest stages of professional training, while studying at college, future mediators need to develop their skills of communication, self-regulation, and empathy. Students need to learn how to hold back their emotions, how to sympathize and perceive the emotional state of another. It may be also remarked that in the modern conditions, the engineer's responsibility for the decisions he made is also growing. The engineer has to see and forecast the consequences of every decision not only from the technical, but also from the human point of view, to prevent any conflicts and communicate well with the colleagues.

Empathy is regarded as one of the factors of mutual understanding essential for socialization, as a condition and result of healthy interpersonal relations and self-actualization of the personality, of the partners' desire to share both positive and negative emotions. In a conflict situation, the person focus on understanding the nature of his partner, to see his emotional state, comprehend the problems and behaviour, to sympathize to understand the other, to be able to "walk in another's shoes". In other words, a critical role is played by such interpersonal relations' regulating mechanism as empathy. L.A. Petrovskaia has emphasized that it is the reflective and empathic position of the conflict parties that ensures decentration in the relationship, but unveiling the conflict situation from different points of view (Petrovskaia, 2007).

Therefore, the relevance of diagnosing the empathy potential of the students learning their professional roles appears obvious. In this research, we relied upon the definition of empathy suggested by V.V. Boyko, who describes empathy as an emotional-rational-intuitive form of reflecting another person (Boyko, 1996).

\section{Research method}

The survey was carried out in three groups of students majoring in psychology, medicine, and technical science aged 18-24. The group majoring in psychology included psychology students from different colleges; there were 55 people, mostly females. The group majoring in medicine consisted of 61 people, with approximately equal shares of males and females. The group majoring in technical science consisted of 58 people, predominantly males.

The survey results were collected by testing the respondents using questionnaires. The conflict behaviour strategy was assessed on the basis of the questionnaire by K.N. Thomas (Metodiki psikhodiagnostiki..., 1990). The empathic ability was scaled under the methodology of V.V. Boyko (Rayogorodskiy, 2017) and the Balanced Emotional Empathy Scale (BEES) by A. Megrabian modified by N. Epstein (Rayogorodskiy, 2017). Observation and individual interviews were carried out to collect additional and back-up information. The survey was carried out in a group, with personal presence. Every participant provided a voluntary consent to being tested.

The collected data were processed using non-parametric criterion for two independent variables of U-Mann-Whitney, the correlation and regression analyses (Nasledov, 2008).

\section{Results}

Let us study the typical strategies of students' behaviour in conflict situations depending on the subject they major in. The method of K.N. Thomas was used to find out that in case of a conflict situation the students of psychology, medicine and technical science use all the five strategies of behaviour. No significant differences in the selection of the preferred strategies were found between the groups. The hierarchy of the students' preferred strategies was also similar (Table 1).

The results presented in Table 1 demonstrate, that regardless of their major, the greatest share of the students prefer to adjust to the conflict situation. The students are ready to go against their interests to avoid confrontation. However, it does not resolve the conflict; the conflict object is just moved on the back burner. When regularly employed, this strategy, on one hand, helps preserve peace with the conflicting party, save energy and have some time to look for a better solution. On the other hand, it de- 
Olga G. Smolyaninova, Svetlana T. Posokhova... The Possibilities of Empathy in Preventing Interpersonal Conflicts...

Table 1. Distribution of conflict behaviour strategies of students of different majors

\begin{tabular}{|c|c|c|c|}
\hline Behaviour strategies & Psychology students (\%) & Medicine students (\%) & Technical science students (\%) \\
\hline Adjustment & 42 & 41 & 39 \\
\hline Competition & 23 & 29 & 24 \\
\hline Avoidance & 14 & 16 & 13 \\
\hline Cooperation & 12 & 10 & 14 \\
\hline Compromise & 9 & 4 & 10 \\
\hline
\end{tabular}

velops passiveness, reduces self-esteem, raises the feeling of insecurity and anxiety. Very often adjustment strategy forms the relationships based on flattering and insincerity, that may cause frustration and disturbance. The problems of personal self-actualization of the students, the difficulty in showing their best in academic activities are among the negative consequences of this strategy.

A little less frequently, the students of all majors prefer the strategy of competition. This strategy implies a firm position in a conflict, a struggle to satisfy one's own interest against the interests of the classmates. The selection of this strategy may be explained by maximalism, confidence in one's opinion as the only right one, which is typical of this age group. Competition is mostly manifested as a persistent struggle to win the confrontation and to achieve the set goal. It may be accompanied by affectation. Unnaturally prominent verbal and non-verbal expressions may cause tension in the group, destructing the mutual respect and trust between the group members. Competition may be often aggravated against the background of a gross insult, employed as a way to combat against the injustice. A catalyst for such situation may be an extreme competition, supported with malevolence demonstrated by the conflict initiator and responsive aggression of the competitor, getting involved into the conflict.

A small share of the students prefers being passive in a conflict situation. Such students usually avoid conflict relations, evading making any decisions hoping that the problem will settle on its own, that any external powers or time will resolve the situation. There is a wide range of behaviour patterns used in this situation, from silence to breaking up the friendly or business relationship with the conflicting party. Such strategy helps gain some time to think the plan over, to find some additional resources to settle the conflict. At the same time, it may result in losing control of the situation, aggravation of anxiety and frustration, losing desire to cooperate with other students and become one of the barriers on the way to one's own goals.

Such situations require interference of specialists, or mediators, who take up the negotiations procedure to help the conflicting parties find a constructive solution. However, mediation cannot be used in all the situations. $\mathrm{Ch}$. Besemer defined the position of mediation as between negotiations and therapy, as during the procedure the participants may elaborate on some deep questions of personal significance, touching on their emotions and life values (Besemer, 2004). In the state of emotional agitation, the conflicting parties experience stress and negative emotions to each other. This is why direct communication between the parties may be non-constructive and disturbing. If a certain phase of conflict appears mediable, a professional intermediary may arrange negotiations to guide the conflicting parties to a winwin resolution and to resume communication.

According to the survey results, the strategies of cooperation and compromise are quite rarely preferred by students for conflict resolution. Only few of them choose to settle the confrontation through reciprocal concessions and search for mutually profiTable solution that would take the interests and values of all conflicting parties into account. Perhaps, the rare use of the strategy is explained by the fact that cooperation and compromise require greater intellectual and emotional effort for resolution of the conflict and satisfaction of the individu- 
al and mutual interests. Moreover, cooperation and successful compromise require the skill of "walking in another's shoes", understanding different points of view and feeling the emotional state of the counterpart. Nevertheless, it should be recognized that these patterns of behaviour are the most efficient in a conflict situation. Just like compromise, cooperation does not only help find the best way out from the conflict, but also strengthens the relations within the group. These strategies may be implemented, when the students are able and ready to show affection for each other, when they are emotionally responsive, taking the interests, values and opinions of each other into account. In other words, they should show empathy for their classmates.

The survey was carried out to scale the general level of empathy, the empathy channels, as well as the emotional responsiveness to the experience of other people. The results collected in the three groups of students majoring in different subjects are presented in Table 2.

General empathy score expresses the person's ability to reach a spiritual togetherness with other people, where deep penetration into the experience of another is a way of temporary identification with another person. Interpreting the collected results, we may remark that psychology students show better general empathic ability compared to students of other majors (differences between the groups are considered statistically relevant at $p \leq 0.05$ ). It is more typical of them to be willing to help and support, to show affection and to care about the personal and emotional problems of other people. Medi- cine students show lower general empathy level, reaching the average value. They are ready to sympathize a person in need. Nevertheless, they are not eager to get absorbed in their emotions and experiences. The demonstration of empathy depends on the own interests and the current emotional condition of these students. Technical science students showed the lowest level of empathy. Their emotional responsiveness, sensitivity and compassion are significantly lower than those of the other two groups. However, they are able to provide support when necessary and to be good listeners. It happens when the communication situation matches their current needs and when they interpret the feelings of their counterpart in the right way.

The research has shown that the students of different majors have both similar and specific features of empathy expression. Commonly for all the students, the emotional component of empathy dominates, while the cognitive component and the intuitive comprehension of the partner are less prominent (Table 2). The dominating emotional empathy channel determines the students' ability to sympathize, commiserate and to show emotional response. For the majority of students from all the group, it is typical not only to express their interest for people, but also to show some emotional response. They have intrinsic emotional sensitivity to the feelings of others and the ability to identify the emotions of their counterparts. The interview results let us assume that the students are sincere in expressing their emotions. They try to demonstrate what they actually feel at the moment of contact, not what they are implied

Table 2. Empathic ability score of students majoring in different subjects

\begin{tabular}{|l|c|c|c|}
\hline \multicolumn{1}{|c|}{ Item } & $\begin{array}{c}\text { Psychology students } \\
\text { (score) }\end{array}$ & $\begin{array}{c}\text { Medicine students } \\
\text { (score) }\end{array}$ & $\begin{array}{c}\text { Technical science } \\
\text { students (score) }\end{array}$ \\
\hline Emotional empathy channel & $5.34 \pm 0.99$ & $5.11 \pm 0.23$ & $5.02 \pm 0.35$ \\
\hline Intuitive empathy channel & $5.02 \pm 0.34$ & $3.12 \pm 0.41$ & $4.36 \pm 0.19$ \\
\hline Rational empathy channel & $4.01 \pm 0.33$ & $3.02 \pm 0.10$ & $2.11 \pm 0.55$ \\
\hline $\begin{array}{l}\text { Empathy-assisting or hin- } \\
\text { dering mindsets }\end{array}$ & $5.31 \pm 0.45$ & $5.23 \pm 0.59$ & $4.11 \pm 0.47$ \\
\hline Penetrative ability in empathy & $5.33 \pm 0.86$ & $4.03 \pm 0.61$ & $2.21 \pm 0.61$ \\
\hline Identification & $5.43 \pm 0.41$ & $4.31 \pm 0.22$ & $2.08 \pm 0.49$ \\
\hline General score & $30.44 \pm 0.56$ & $24.82 \pm 0.36$ & $21.87 \pm 0.44$ \\
\hline
\end{tabular}


to feel by the social standards of behaviour in different situations. It may be concluded that the students feature not only emotional responsiveness, but also emotional authenticity.

Based on the presented result, we may suggest that in interpersonal relationships the majority of students are guided by their emotional impressions. However, the major of studies makes a certain impact on differentiation of the level of emotional empathy as a capacity of emotional response to another person's feelings. In the general sense, emotional response implies experiencing the emotion of the same sort as the communication counterpart. Comparison of the results to the data collected with A. Megrabian questionnaire shows that the students majoring in psychology, medicine, and technical science have different capacity of emotional response. The highest emotional response ability is more typical of psychology students. Among future psychologists, $23 \%$ of respondents are able to commiserate and to feel what another person feels, to experience the same emotional state. Identifying oneself with the communication counterpart at the emotional level means focusing the consciousness, first of all, on the needs of that person and pushing one's own needs to the background. High-level emotional response is less common among future doctors and engineers: $11 \%$ and $4 \%$ respectively (differences from the group of psychologists are considered statistically relevant at $\mathrm{p} \leq 0.05$ ). They are less prone to emotional responsiveness; they are less focused on the shades of emotions of the counterparts and are not always able to clearly express their own emotions both verbally and non-verbally.

The differences are seen in the results of comparison between the medium and low levels of emotional empathy. Among psychologists, the students with middle level of emotional responsiveness are more common than among future doctors (differences between the groups are considered statistically relevant at $\mathrm{p} \leq 0.05$ ). In interpersonal relations, these students are more inclined to judging others by their deeds and actions rather than trusting their personal impressions. As a rule, they have difficulty differentiating emotional expressions and understanding the hidden behaviour motivation, as well as forecasting relationships between people. Their strong point is controlling their own emotional reactions during personal contact.

Low level emotional response is quite clearly differentiated depending on the students' major. In the group of future psychologists, the share of students with low level of emotional response is only $5 \%$; in the group of medicine students, there are $16 \%$, and in the group of technical science students, there are $21 \%$ (difference between the groups are considered statistically relevant at $\mathrm{p} \leq 0.05$ ). Such students usually have problems understanding the emotional reactions of their classmates. Empathic comprehension of the individuality and shades of emotions of another person is replaced with stereotypical judgements, cliché behaviour pattern of an average person. In social life, they are prone to applying doubtful patterns of assessing other people based on their own limited experience, on worldly pseudo-wisdom and biased judgements. As a result, they do not find understanding in the group, they feel uncomfortable, and may use aggression to defend their personal borders.

Analysing the empathy structure, we notice that in interpersonal contacts students use the cognitive and behaviour channels less common than the emotional one. This proportion is the same regardless of the students' major (Table 2). The cognitive element of empathy is understood as demonstration of spontaneous interest to the nature of person and ability to identify both one's own emotions and the emotions of other members of the group. However, many students turned out to be not good enough at identifying their own emotions, and, therefore, to be often mistaken in interpreting other people's feelings. The interview results bring the conclusion that for many students, such difficulties are born by their fear of their own emotions and feelings, by the incapacity of expressing their emotions verbally and non-verbally, as well as by their own expressiveness. They are more focused on their own needs, motives, and mindsets. Such cognitive limitation of emotions causes conflicts, breaks connection with the group and the cohesion of the group as a whole. In the future, it may 
become a serious obstacle to the professional actualization of the person, particularly in the situations of communication.

The comparison of the three groups of students revealed that the future psychologists are more clearly focused on using the cognitive channel of empathy than the medical and technical science students (difference between the group is statistically relevant at $\mathrm{p} \leq 0.05$ ). Besides, future psychologists and engineers have a well-developed intuitive channel of empathy, even though it does not reach the high level threshold (difference from the medicine students' group is statistically relevant at $\mathrm{p} \leq 0.05$ ). It may be concluded that students majoring in psychology are more attentive to the details of communication situations compared to students of other majors, though the general context of communication is also important for them. This approach helps them accumulate the experience stored in their consciousness and subconsciousness, foresee the behaviour of their partners, and to act with the deficit of input information of their counterparts. Therefore, they have an ability to generalize various, often contradictory forms of behaviour at the intuitive level, which makes it easier for them to run negotiations in conflict situations.

Emotional response is not the only aspect of empathic abilities. An important role is also played by the empathic mindsets that may strengthen or weaken the empathic activity. The mindsets determine the involvement of this or that channel of empathy. The results presented in Table 2 show that the mindsets of psychologists activate their empathic abilities in the interpersonal relations. It becomes especially visible in comparison with the students majoring in technical science (differences between the group are considered statistically relevant when $\mathrm{p} \leq 0.05$ ). The psychology students feature an internal readiness to identify the emotional states when the person needs support, and to get involved with their sympathy. They are ready to trust their first impressions, often relying upon stereotypical judgements formed by the psychological disciplines included into their curriculum. However, at the same time, they feature the so-called penetration ability, or the ability to create the atmosphere of open- ness and trust, rather than other students (see Table 2). This personal quality makes them different from medicine students, and especially from technical science students (differences between the groups are considered statistically relevant when $\mathrm{p} \leq 0.05$ ). Let us remark that among future engineers there were more students who tend to avoid personal contacts, depreciate the atmosphere of openness, trust, and warm sincerity. Defending their behaviour and personality, they say they find it inappropriate to demonstrate their curiosity for another person; they convince themselves to be indifferent to the feelings and problems of others. These mindsets limit the diapason of the emotional responsiveness and create the grounds for intrapersonal and interpersonal conflicts.

Among the essential conditions of successful empathy, there is identification, or the ability to understand another person using sympathy and ability to "walk in the other's shoes". Identification requires lightness, agility and flexibility of emotions, as well as talent for imitation. The survey results bring the conclusion that the psychology students are more capable of understanding another person using sympathy, making assumptions about the internal state of their communication counterpart, walking in their shoes, looking at things from their perspective. Even though the students majoring in psychology and medicine are able to listen to their interlocutors almost with equal penetrating empathy, among future psychologists there are more people who show flexibility of communication, who are able to "try on" the emotional experience of another person without identifying that experience as their own (differences between the groups are considered statistically relevant at $\mathrm{p} \leq 0.05$ ).

As a personal quality regulating the relationships between the members of the education communication, empathy carries an important social role. Properly developed empathy is one of the factors of preventing conflicts among students. It is proven, first of all, by the dependency of the students' conflict behaviour patterns and the empathy development values; secondly, of the forecasting influence of the empathy indicators on the attitude of the students to each other. 
Moreover, it was found that the preference of the cooperation style in the conflict is directly connected with the general level of empathy $(\mathrm{r}=0.409$ at $\mathrm{p} \leq 0.01)$, the emotional channel of empathy $(\mathrm{r}=0.448$ at $\mathrm{p} \leq 0.01)$, and the cognitive channel $(\mathrm{r}=0.349$ at $\mathrm{p} \leq 0.05)$ and settings that promote empathy $(r=0.460$ at $\mathrm{p} \leq 0.01)$. Those students who are focused on cooperation have better developed empathic abilities. It is important to keep in mind the opposite: developed empathic abilities are combined in the conflict with the focus on mutually beneficial solutions.

The strategy of compromise in the conflict involves primarily the emotional channel $(r=0.448$ at $p \leq 0.01)$ and identification $(\mathrm{r}=0.441$ at $\mathrm{p} \leq 0.01)$ in the empathy. In turn, understanding the emotional state of the opposing side and empathy allow students to come up with compromise solutions. The opposite is the relationship between preference for confrontation and empathy. The confrontation strategy is combined with low emotional $(r=-0.409$ at $\mathrm{p} \leq 0.01)$ and cognitive $(\mathrm{r}=-0.579$ at $\mathrm{p} \leq 0.01)$ empathy. It is also possible that with poorly developed emotional and cognitive channels of empathy, tense relations between students in a conflict situation are possible. Such a style in the conflict as adaptation is typical for students with an overestimated level of the emotional component of empathy $(r=0.379$ at $\mathrm{p} \leq 0.05)$. Students with a high level of emotional empathy are ready to give up their own interests and abandon their own point of view for the sake of good relations in the team.

With the correlation analysis, we have determined the most significant relations between the empathy indicators and the conflict behaviour styles. We found out that the underlying system-forming components of the freshmen's empathy were the empathy-stimulating mindsets and the cognitive channel of empathy. Moreover, the selection of the cooperation style of conflict behaviour was found to be directly connected to the general level of empathy (0.409), the emotional channel of empathy (0.448), the cognitive channel (0.349) and the empathy-stimulating mindsets (0.460). The students focused on cooperation feature better developed empathy abilities. It is also important to mind the opposite: the well-developed empathy ability is usually combined with the tendency of looking for win-win solutions in a conflict situation.

The compromise strategy in a conflict implies, first of all, the engagement of the emotional (0.448) and identification channels (0.441) of empathy. In its turn, comprehension of the emotional state of the confronting party and sympathy guide the students to choosing compromise solutions. The confrontation strategy is opposite to empathy. It is combined with the low emotional (0.409) and cognitive (0.579) empathy. It is also possible that the underdeveloped emotional and cognitive channels of empathy may cause tense relations between students in a conflict situation. The adjustment style of conflict behaviour is usually employed by the students with excessive level of the emotional component of empathy $\left(0.379^{* *}\right)$. Students with high emotional empathy level are ready to sacrifice their own interests and to give up their point of view for the sake of good relations in the group.

The need for intentional development of empathic abilities of students is proven by the revealed forecasting role of some empathy indicators that manifest themselves in the attitude of regular students to those with musculoskeletal disorders. It should be remarked that in the life experience of the students majoring in psychology and technical science there have been no actual conflicts with people with disabilities like cerebral palsy. This fact of their biography could make an impact on their system of attitude to persons with disabilities. Moreover, future psychologies and future engineers are generally positive to this category of students, which is actively expanding due to the integration processes at higher educational institutions. However, it is quite moderate: $1.12 \pm 0.95$ points for psychology students and $0.81 \pm 0.91$ points for technical science students. Let us emphasize that the students perceive their classmates with disabilities as professional competitors: $2.12 \pm 0.73$ points for future psychologists and $2.23 \pm 0.80$ points for future engineers. If 3 is the maximum value of this indicator in the present research, the possibility of such competition is quite high. In such competitive situation, tension in the relationships 
between students is possible. Moreover, the students of different majors believe in the possibility of professional success for the people with disabilities. The likeliness of professional success of the disabled people is assessed as $2.79 \pm 0.48$ points by future psychologists and $2.58 \pm 0.72$ points by future engineers.

In this situation, there arises a question about the role of empathy in preventing conflict situations. To understand the influence of empathy on the forecast of the attitude to a classmate with MSD, the method of multiple regression analysis was used. It was found out that this influence is selective. At the present stage of research, it is hard to speak of the two components of empathy significant for forecasting the prevention of conflicts between students with different health conditions. It is about the development level of the rational channel of empathy and the penetration ability. Thus, the rational channel makes a positive impact on the possible appearance of a classmate with MSD in the group $(\beta=0.16)$. For students with a well-developed rational channel, it is common to understand the nature of another person, to feel a sincere and spontaneous interest to another, which is especially important at the first stage of the students' group formation. It is the empathy, and, first of all, its penetrating ability, that determines the assumption of the possible comforTable position of a person with disability in this or that student group $(\beta=0.12)$. In this case, the prevention of conflicts depends on the openness, cognitive interest of the students and search for a new positive communication experience, typical for young people.

\section{Conclusion}

Students have always been a special social stratum of society. Exposed to various sociocultural factors and being on the border between youth and adulthood, the student youth strives not only to gain independence from their parents, but also to make their own critical conclusions on everything that is going on with the society and in the society. As representatives of the new generation, students overcome the judgements and stereotypes of the previous generations, at the same time creating their own. Perhaps this is what determines their readiness for the conflict social relations. The sociocultural situation and the psychological tasks of this age set the range of common behaviour patterns employed in the conflict situations and the empathic abilities of students of different majors. This may be considered as an advantageous factor for training specialists in mediating conflicts in the domain of education, and higher education in particular.

The revealed levels of empathy, distribution of its components and the general development of empathy generally correspond to the personal and professional profile of the students majoring in psychology, medicine, and technical science. There are some theoretic and practice proofs that empathy is a professionally relevant quality and a natural personal feature of any psychologist. Those are the emotional empathic abilities that determine one's selection of psychology as a profession, in the professional breeding of a young specialist and in overcoming the sense of professional helplessness. However, excessive concentration on the feelings of others may cause emotional addiction, develop unhealthy vulnerability and touchiness. At the same time, the possibility of developing psychosomatic diseases is also high. As a result, a wide circle of barriers for effective professionalization and socialization as a whole is drawn.

Experiencing difficulty in identifying emotions of other people is more typical for engineering students. It should be considered when training mediation specialists, as technically oriented people are more likely to find themselves in professional and family conflicts than humanities-minded ones. Moreover, the current socioeconomic situation and career expectations of the company managers require college graduates to demonstrate such qualities as initiative, sociability, ability to regulate relationships that arise in the joint activities of people, readiness to adjust to the dynamically changing working conditions and the management decisions that may not always be popular and inspiring. This is what increases the social and personal relevance of developing empathy as a separate branch of professional training at higher educational institutions. This problem is getting more acute 
in technical colleges due to the domination of technical subjects in the curriculum. Schools of medicine and, particularly, psychology establish the foundation of the professional communication skills through humanitarian courses. The opinion that engineers do not need psychology, philosophy, pedagogy etc. is nothing but a myth of the superiority of technology and information in our life. In today's reality of engineering, the need for psychologization is rapidly growing. The engineers working at production sites have to deal with massive and semantically diverse flows of information that need to be received, properly processed and forwarded by different channels of communication. This process is impossible without personal communication skills.

It is worth noticing that there are many reasons that hinder deep and penetrating empathy. One of them lies in activation of psychological defence from negative emotional states, psychological discomfort and projection of one's own experience to other people, "attributing" one's inner world to another. Doubtlessly, it is important to take the limited personal communication experience into account. Last but not least, one of the main tasks of the young age is to provide the need for professional and family self-actualization, which also enhances the egocentric mindsets of the person.

\section{References}

Besemer, Ch. (2004). Mediatsiia. Posrednichestvo v konfliktakh [Mediation. Intermediation in Conflicts]. Kaluga: Dukhovnoe Poznanie, 179 p.

Boyko, V.V. (1996). Energiia emotsiy v obshchenii [Energy of Emotions in Communication]. Moscow: Filin Information and Publishing House, $472 \mathrm{p}$.

Chiker, V.A. (2019). Mobbing kak sotsial'no-psikhologicheskiy fenomen [Mobbing as a Sociopsychological Phenomenon]. In Sotsial'naia psikhologiia obshcheniia: teoriia i praktika [Social Psychology of Communication: Theory and Practice], edited by S.D. Gurieva, L.G. Pochebut, A.L. Sventsitsky. Moscow: INFRA-M. P. 189-207.

Christian, D. (2008). The Cortex: Regulation of Sensory and Emotional Experience, In Art Therapy and Clinical Neuroscience. Noah Hass-Cohen and Richard Carr (eds.). London and Philadelphia: Jessica Kingsley Publishers, 62-75.

Eleferenko, I.O. (2010). Nravstvennost' kak uslovie ponimaniia sinergeticheskogo podkhoda k empatii [Morality as a Condition of Understanding the Strategic Approach to Empathy]. In Mir obrazovaniia obrazovanie v mire [World of Education - Education in the World], 1 (37), 92-100.

Gomyranova, O.N. (2006). Mezhlichnostnye konflikty vo vzaimootnosheniiakh studentov vuzov [Interpersonal Conflicts in the Relationships between Higher Educational Institution Students]. In Astrakhan State Technical University Newsletter. Astrakhan: SEU HPE “Astrakhan State Technical University”, 5 (34), 301-305.

Grishina, N.V. (2005). Psikhologiia konflikta [Conflict Psychology]. St. Petersburg: Piter, 464 p.

Gurieva, S.D. (2015). Taktiki i strategii vedeniia peregovorov [Tactics and Strategies of Negotiations]. St. Petersburg: St. Petersburg State University, 132 p.

Gurieva, S.D., Udavikhina, U.A. (2019). Stili peregovorov v situatsii ogranichennykh resursov i neopredelennosti: korotkie i dlitel'nye kommunikatsii [Negotiation Styles in the Situation of Limited Resources and Uncertainty: Short and Long Communication]. In Sotsial'naia psikhologiia obshcheniia: teoriia i praktika [Social Psychology of Communication: Theory and Practice], edited by S.D. Gurieva, L.G. Pochebut, A.L. Sventsitsky. Moscow: INFRA-M. P. 302-321.

Gonzalez-Liencres, C., Shamay-Tsoory, S.G., Brüne, M. (2013). Towards a Neuroscience of Empathy: Ontogeny, Phylogeny, Brain Mechanisms, Context and Psychopathology. In Neuroscience and Biobehavioural Reviews, 37 (8), 1537-1548.

Jackson, P.L., Meltzoff, A.N., Decety, J. (2005). How Do We Perceive the Pain of Others? A Window into the Neural Processes Involved in Empathy. In Neuroimage, 24 (3), 771-779.

Kariagina, T.D., Ivanova, A.V. (2013). Empatiia kak sposobnost': struktura i razvitie v khode obucheniia psikhologicheskomu konsul'tirovaniiu [Empathy as Ability: Structure and Development in the Pro- 
cess of Psychological Counselling Training]. In Konsul'tativnaia psikhologiia i psikhoterapiia [Counselling Psychology and Psychotherapy], 21 (4), 182-207.

Krasnoperova, N.A. (2016). Strategii povedeniia studentov v konfliktnykh situatsiiakh [Patterns of Students' Behaviour in Conflict Situations]. In Sbornik: Mir cheloveka [Collection of articles: Human World]: scientific and information journal], 1 (44). Krasnoyarsk, Siberian State Technical University, 84-90.

Lieberman, E., Foux-Levy, Y. \& Segala, P. (2005). Beyond Basic Training: Model for Developing Mediator Competence. Conflict Resolution Quarterly, 23 (2), 237-257. Wiley Periodicals, Inc. and the Association for Conflict Resolution.

Metodiki psikhodiagnostiki v uchebno-vospitatel'nom protsesse [Psychodiagnostic Methods in the Leaning and Teaching Process] (1990). Compiled by Grishin, V.V., Lushin, P.V. Moscow: IKA Moskva, $65 \mathrm{p}$.

Mikhaylova, G.V. (2004). Podgotovka studentov k razresheniiu konfliktov v uchebnykh gruppakh (na primere tekhnicheskogo universiteta) [Preparing Students for Resolving Conflicts in Learning Groups (based on the example of a technical university)]. Thesis of a Candidate of Pedagogy, Arkhangelsk, $148 \mathrm{p}$.

Nasledov, A.D. (2008). SPSS 15: Professional'nyy statisticheskiy analyz dannykh [SPSS 15: Professional Statistic Data Analysis]. St. Petersburg: Piter, 412 p.

Petrovskaia, L.A. (2007). Obshchenie - kompetentnost' - trening: izbrannye trudy [CommunicationCompetence - Training: Collected Works]. Moscow: Smysl, 387 p.

Panferov, V.N. (2015). Integral'nyy sintez psikhologii cheloveka v nauke, obrazovanii, v sotsial'nom vzaimodeystvii [Integral Synthesis of the Human Psychology in Science, Education, Social Relationship]. St. Petersburg: Herzen Russian State Pedagogical University, 760 p.

Posokhova, S.T., Shemeteva, Ia.S. (2017). Novye rakursy obrazovatel'noy sredy vuza: mezhlichnostnoe vzaimodeystvie studentov s raznymi vozmozhnostiami zdorov'ia [New Aspects of the Higher Educational Institution Environment: Interpersonal Relations between Students of Different Physical Abilities]. In Problemy psikhologo-pedagogicheskoy raboty v sovremennom obrazovatel'nom uchrezhdenii [Problems of Psychological and Pedagogical Work at a Modern Educational Institution], edited by V.M. Golianich, O.V. Khodakovsaia. St. Petersburg: NITS ART, 490-499.

Rayogorodskiy, D.Ia. (2017). Prakticheskaia psikhodiagnostika. Metodiki i testy [Practical Psychodiagnostics. Methods and Tests]. Moscow: Makhrakh-M. 672 p.

Savva, L.I., Soldatchenko, A.L. (2015). Sotsial'noe vzaimodeystvie kak strukturnyy komponent sotsial'noy zrelosti studenta vuza [Social Interaction as a Structural Component of Social Maturity of a Higher Education Student]. In Sovremennaia vysshaia shkola: innovatsionnyy aspect [Contemporary Higher Education: Innovative Aspect], 4, 147-153.

Smolyaninova, O.G., Korshunova, V.V. (2019). Otnoshenie uchastnikov obrazovatel'nogo prostranstva Krasnoiarskogo kraia k mediativnym praktikam [Attitude of the Members of the Education Domain of the Krasnoyarsk Territory to the Mediation Practices]. In Science for Education Today. Novosibirsk: Novosibirsk State Pedagogical University, 9 (3), 7-27.

Smolyaninova, O.G., Popova, Zh.V. (2019). Specific issues of training intercultural mediators for education in Europe and Russia. In Journal of Siberian Federal University - Humanities and Social Sciences, 12 (2), 247-260. DOI: 10.17516/1997-1370-0392

Smolentseva, A.Iu. (1998). Sotsial'nye konflikty v vysshey shkole v usloviiakh perekhoda k rynochnoy ekonomike [Social Conflicts at Higher Education in the Transition to Market Economy]. Abstract from the Thesis of the Candidate of Sociology. Moscow: Lomonosov Moscow State University, 19 p.

Titkova, L.S. (2004). Vnutrigruppovaia konfliktnost' studentov sovremennykh rossiyskikh vuzov $i$ faktory, vliiaiuschie na nee (po materialam sotsiologicheskogo issledovaniia vuzov Primorskogo Kraia) [Intergroup Conflicts of Students of the Modern Russian Higher Educational Institutions and the Factors Influencing it (based on the sociological study of higher educational institutions of the Primorsky Territory)]. Thesis of the Candidate of Sociology. Vladivostok, $170 \mathrm{p}$.

Khasan, B.I., Sergomanov, P.A. (2003). Psikhologiia konflikta [Conflict Psychology]. Moscow: Academia, $192 \mathrm{p}$. 
Kholina, O.A., Petrova, E.G. (2017). Issledovanie predstavleniy studentov o mezhlichnostnykh konfliktakh (na primere studentov russkoy i ukrainskoy natsional'nostey) [Research of the Students' Ideas of Interpersonal Conflicts (based on the example of Russian and Ukrainian students)]. In Psikholog [Psychologist], 6, 1-10.

Shamlikashvili, Ts.A. (2010). Mediatsiia kak al'ternativnaia protsedura uregulirovaniia sporov [Mediation as an Alternative Conflict Resolving Procedure]. Moscow: MCUPK, $160 \mathrm{p}$.

Shamlikashvili, Ts.A. (2014). Mediatsiia kak mezhdistsiplinarnaia nauka i sotsial'no znachimyy institut [Mediation as an Interdisciplinary Science and Socially Relevant Institution]. In Psikhologicheskaia nauka i obrazovanie [Psychological Science and Education], 2, 5-14.

Utlik, V.E. (2010). Psikhologicheskiy klimat studencheskoy gruppy [Psychological Climate in a Student Group]. In Innovatsii v obrazovanii [Innovations in education], 8, 32-42. 


\title{
Возможности эмпатии в предупреждении
}

\section{межличностных конфликтов в образовательной среде вуза}

\author{
О.Г. Смолянинова ${ }^{a}$, С.Т. Посоховаб ${ }^{6}$ М.Х. Изотоваб \\ ${ }^{a}$ Сибирский федеральньй университет \\ Российская Федерачия, Красноярск \\ ${ }^{6}$ Санкт-Петербургский государственный университет \\ Российская Федерация, Санкт-Петербург
}

\begin{abstract}
Аннотация. В статье рассматриваются возможности эмпатии в предупреждении межличностных конфликтов в сфере высшего образования. Межличностные конфликты раскрываются с социально-психологических позиций как многомерное явление, возникновение и развитие которого обусловливаются личностными особенностями субъектов образовательного процесса. Успешность медиации в конфликте между обучающимися определяется знанием факторов, которые способствуют снижению вероятности возникновения конфликтной ситуации. Эмпатия - это одна из личностных особенностей, которая может быть использована для предупреждения развития конфликтных ситуаций и расширения спектра медиативных технологий. В эмпирическом исследовании участвовали студенты психологического, медицинского и технического профилей обучения в возрасте от 18 до 24 лет. Были использованы опросники диагностики уровня эмпатических способностей В.В. Бойко, А. Меграбиана. Установлено, что эмпатия наиболее выражена у студентов-психологов. Эмпатия способствует сближению обучающихся, ограничивает агрессивные тенденции, блокирует конкурентное отношение к студентам с ограниченными возможностями здоровья. Благодаря эмпатии формируются основы нейтральности в оценке взаимоотношений между конфликтующими сторонами, что необходимо для предупреждения межличностных конфликтов. Делается вывод о важности развития эмпатических способностей у обучающихся, специализирующихся в сфере медиации.
\end{abstract}

Ключевые слова: межличностный конфликт, медиация, психология конфликта, эмпатия, нейтральность, юношеский возраст.

Исследование выполнено при финансовой поддержке Российского фонда фундаментальных исследований в рамках научного проекта № 18-013-00528 «Исследование медиативных практик в сфере образования для гармонизации межнациональных отношений в поликультурной среде».

Научная специальность: 44.04.02 - психолого-педагогические науки. 